\title{
COUNTERMEASURES AGAINST THE INTRODUCTION AND SPREAD OF CORONAVIRUS INFECTION COVID-19 IN MEDICAL ORGANIZATIONS
}

Nikiforov $\mathrm{W}^{1,2}$, Suranova TG ${ }^{1,3} \otimes$, Komarevtsev VN ${ }^{3,4}$, Khlutkov SYu ${ }^{5}$, Skvortsova VI

${ }^{1}$ Academy of Postgraduate Education under the Federal State Budgetary Unit "Federal Scientific and Clinical Center for Specialized Medical Assistance and Medical Technologies of the Federal Medical Biological Agency", Moscow, Russia

${ }^{2}$ Pirogov Russian National Research Medical University, Moscow, Russia

${ }^{3}$ Russian Center for Disaster Medicine "Zashchita" of FMBA of Russia, Moscow, Russia

${ }^{4}$ National Medical Research Center Rehabilitation and Balneology, Moscow, Russia

${ }^{6}$ Federal Medical and Biological Agency, Moscow, Russia

The article presents a brief epidemiological characteristic of a new coronavirus infection. The risks of infection of medical workers and measures to counter the drift and spread of COVID-19 in medical organizations are considered.

Keywords: COVID-19, coronavirus infection, medical organizations, sanitary and anti-epidemic measures, infectious safety

$\bowtie$ Correspondence should be addressed: Suranova G. Tatyana

ur.liam@anaitatavonarus

Received: 19.06.2020 Accepted: 29.07.2020 Published online: 10.08.2020

DOI: $10.47183 /$ mes.2020.008

\section{МЕРЫ ПРОТИВОДЕЙСТВИЯ ЗАНОСУ И РАСПРОСТРАНЕНИЮ КОРОНАВИРУСНОЙ ИНФЕКЦИИ COVID-19 В МЕДИЦИНСКИХ ОРГАНИЗАЦИЯХ}

\author{
В. В. Никифоров ${ }^{1,2}$, Т. Г. Суранова ${ }^{1,3}$, В. Н. Комаревцев ${ }^{3,4}$, С. Ю. Хлутков ${ }^{5}$ В. И. Скворцова
}

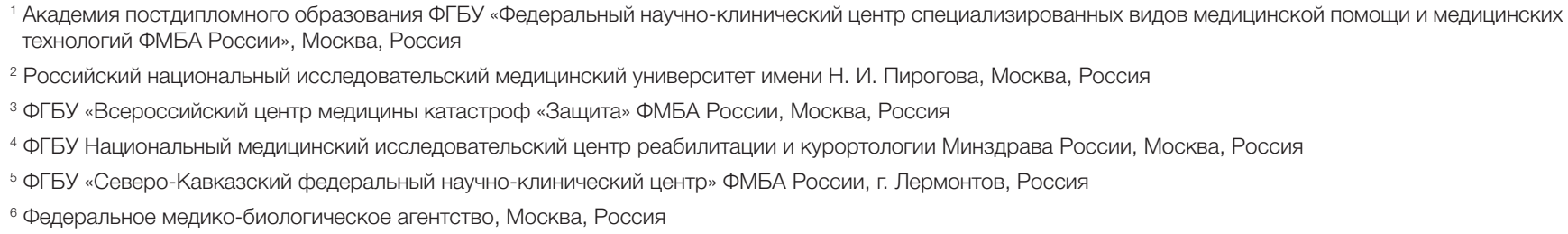

В статье представлена краткая эпидемиологическая характеристика новой коронавирусной инфекции. Рассмотрены риски инсицирования медицинских работников и меры противодействия заносу и распространению COVID-19 в медицинских организациях.

Ключевые слова: COVID-19, коронавирусная инфекция, медицинские организации, санитарно-противоэпидемические мероприятия, меры инфекционной безопасности

$\bowtie$ Для корреспонденции: Суранова Татьяна Григорьевна

ur.liam@anaitatavonarus

Статья получена: 19.06.2020 Статья принята к печати: 29.07.2020 Опубликована онлайн: 10.08.2020

DOI: $10.47183 /$ mes.2020.008

Viruses stand out from other dangerous pathogens as capable of causing global outbreaks of deadly infections posing a threat to mankind. Emerging high-consequence infectious diseases of the 21st century include severe acute respiratory syndrome (SARS, 2002), Middle East respiratory syndrome (MERS, 2012), H5N1 avian influenza (2007), A (H1N1) pdm swine flu (2009), Zika, and the list can be continued. In 2014 2015, Ebola spread to new territories in West Africa; brought to Europe, it exposed how ill-prepared European public health systems were for a biological threat [1].

However, the novel coronavirus has surpassed the foregoing infections in scale and escalated into a pandemic in a matter of months. The first cases of previously unknown pneumonia were reported at the end of December, 2019 in Wuhan (Hubei Province, Central China). On January 30, WHO defined the outbreak of the novel coronavirus infection as a public health emergency of international concern. On February 11, 2020 WHO announced a name for the novel coronavirus disease (COVID-19), following the notification of the National Health Commission of the People's Republic of China on the provisional name for the novel coronavirus pneumonia (February 9, 2020). On March 11, 2020 WHO declared a pandemic.

Over the past decade, 4 new coronaviruses have been discovered. Viral mutations are the primary cause underlying the emergence of novel viruses and viral strains. Conspiracy theories about their laboratory origin are not discussed in this paper for obvious reasons.

Mutations make viruses more contagious, pathogenic and capable of crossing the species barrier and invading new hosts. Infections caused by emerging pathogens and mutant strains of previously known microorganisms have a more severe course because the host lacks defense mechanisms against the unknown pathogen.

The novel coronavirus has rapidly spread across the globe. This suggests that we have limited knowledge about the potential of zoonotic viruses; human encroachment on wildlife habitat, expansion of transport networks, increasing migration, climate changes, advances in biotechnology and other factors will significantly increase the risk of such plagues in the future [2].

The COVID-19 pandemic exposed vulnerabilities of public healthcare systems. Many countries failed to organize public 
health surveillance, promptly respond to the increasing need for protective personal equipment (PPE), sufficient bed capacity and mechanical ventilators, coordinate the work of auxiliary services, etc. [3].

Countries that managed to create centers for coordinated response against COVID-19 are the most successful in fighting the infection by reinforcing sanitary control, providing medical care, developing diagnostic methods, therapies and vaccines.

The turn of year 2019/20 has taken its place in history as the time of the COVID-19 pandemic. The novel coronavirus infection is an acute infection that predominantly affects the respiratory tract and is caused by SARS-CoV-2, an RNA virus from the Betacoronavirus genus of the Coronaviridae family. SARS-CoV-2 is putatively derived from a recombination of a bat coronavirus and an unidentified coronavirus. SARS-CoV-2 has over $80 \%$ sequence homology with SARS-CoV.

The causative agent of COVID-19 is a Risk Group II pathogen. COVID-19 was included in the list of diseases posing a community threat [Executive order № 66 of the Government of the Russian Federation dated January 31, 2020].

The COVID-19 pandemic is characterized by a high transmission rate: the virus spreads via respiratory droplets, has a long incubation period and can be asymptomatic in contagious individuals; at the moment, there is no vaccine and etiotropic treatment against the virus.

Close-knit communities with actively interacting members, including rotational shift workers, healthcare workers or people living in social care facilities, are a cauldron for COVID-19. Herd immunity and specifically postvaccination immunity against COVID-19 will slow down the spread of the disease.

At the Member State Briefing on the COVID-19 pandemic evaluation held on July 9, 2020, WHO Director-General Tedros Adhanom Ghebreyesus said that "the pandemic is still accelerating".

\section{Epidemiological situation}

As on July 18, 2020, about 14 million COVID-19 cases were reported worldwide and approximately 600,000 people died. So far, 800,000 COVID-19 cases and 12,000 deaths have been reported in Russia [1] Hundreds of COVID-19 hotspots have been identified, including healthcare facilities.

Preventing the spread of the novel coronavirus in healthcare settings is of critical importance. In the absence of vaccines and effective etiotropic treatments against COVID-19, infection prevention and control measures have become the mainstay of fighting the disease. Guidelines have been developed for healthcare personnel working with patients who seek medical care during the pandemic [4].

Healthcare workers are at very high risk for COVID-19. Thousands of health workers worldwide contracted the virus when providing medical care to infected patients. One of the underlying causes is lack of training: frontline health workers, except for infectious disease specialists, are not trained in infection prevention and control (including infections with droplet transmission)[5].

Infected patients are an increasingly common source of nosocomial COVID-19. However, there is mounting evidence that physicians, nurses, technicians, hospital elevator operators, cleaners, and security guards can also be the source of the virus. There are reports of patients infected by their attending physicians who were on vacation abroad but did not self-isolate for 14 days on return. Some patients admitted to non-COVID hospitals concealed the fact that they had travelled to diseasestricken countries or had physical contact with infected family members.
It is known that viral shedding occurs as early as $48 \mathrm{~h}$ before the onset of symptoms, peaks at days 1-3 from onset and continues through day 12 in mild/moderate cases and through day 14 in severe cases.

Transmission through respiratory droplets occurs during close physical contact ( $>15 \mathrm{~min}$, at $<2 \mathrm{~m}$ distance) with an infected individual who has respiratory symptoms. Walking past an infected patient in a lobby is not so dangerous. Coughing and sneezing patients expel virus-containing aerosols from their respiratory tract. If these particles land on the oral/nasal mucosa or the conjunctiva of a susceptible individual, they cause infection.

Another route of transmission is through airborne dust particles. SARS-CoV-2 has been found to retain its viability for up to 3 days in large drying mucus droplets that fall on fomites, from where the virus can travel further on dust [6].

In healthcare settings, the virus can be transmitted through medical equipment, such as a pulse oximeter, thermometer, other devices near the infected individual, fomites (door handles, smartphone screens), food or water. The virus can spread through hand-to-eye, hand-to-nose or hand-to-mouth contact.

There is evidence of fecal-oral transmission. It is reported that viral RNA is detected in stools of convalescent individuals for 4 weeks. The nucleocapsid protein of SARS-CoV-2 was detected in the cytoplasm of the epithelial cells in salivary glands, the stomach, the duodenum, the rectum, and the urinary system. The virus might replicate in the liver and the intestine [6].

The risk of infection increases if a person does not adhere to infection prevention measures.

Measures for protecting healthcare workers against COVID-19 include using engineering and administrative controls and PPE. Control of infection sources is of fundamental importance. Each patient should be viewed as potentially infected with COVID-19. Measures for controlling the source of infection include early diagnosis, case detection, identification of asymptomatic patients, isolation of infected patients and individuals with suspected COVID-19.

In order to prevent the spread of COVID-19 in healthcare facilities, it is imperative that:

- patients suspected to have COVID-19 be accommodated in isolation rooms or rooms with an airlock lobby and a dedicated bathroom; patients with different COVID-19 severity and at different stages of the disease should not be cohorted in the same ward;

- patients suspected to have COVID-19 be housed in single rooms; patients with confirmed COVID-19 admitted to an infectious disease hospital can be housed together (2-4 persons in the room) if their beds are at least 1.5-2 $\mathrm{m}$ apart and the minimum space per person is $8 \mathrm{~m} 2$, as required by the sanitary regulations;

- patients wear face masks in the presence of healthcare workers or other patients; hand hygiene should be performed;

- patients do not leave their wards; mobile phones are allowed (also in intensive care units) but must be disinfected with an alcohol-based sanitizer [7].

Administrative and engineering controls include limiting the number of health workers who have direct contact with patients, minimizing the number of visits to the ward, using telehealth technologies to consult patients. Single-use or dedicated devices (phonendoscopes, blood pressure cuffs, pulse oximeters and thermometers) should be preferred.

Disinfection is one of the central measures for infection prevention and control. SARS-CoV-2 has been proved to be 
sensitive to UV light and high temperatures. Exposure to $56^{\circ} \mathrm{C}$ for 39 min or to $70{ }^{\circ} \mathrm{C}$ for 5 min kills the virus. Disinfectants, including chlorine-based, active-oxygen base, and others, can effectively inactivate the virus. Routine indoor disinfection with disinfectants approved for use near people can be performed in the presence of a patient. Used dishes/utensils, linen, items of care should be soaked in disinfecting solutions.

Hand hygiene using antiseptics for skin disinfection should be performed by medical personnel after each contact with the skin of the infected patient (or suspected to have COVID-19), their mucous membranes, secretions, dressings and items of care near the patient. In the presence of people, indoor air can be decontaminated using UV recirculators and filtration systems (including electric-powered systems).

Medical waste, including patients' secretions (feces, urine, sputum, etc.), is highly hazardous class B waste and should be subject to physical decontamination by exposure to thermal energy, microwaves or radiation; this means that a medical facility should be adequately outfitted with specialized equipment. Disposal of non-decontaminated class B medical waste outside the premises is prohibited. After applying physical methods of decontamination, this waste can be temporarily stored, accumulated, transported, destroyed and buried together with class A waste. Chemical disinfection can be used for decontaminating food and patients' secretions only.

In COVID-19 hotspots, terminal disinfection must be performed with chlorine-based and active oxygen-based agents since they are the most reliable and effective against enveloped viruses, including the novel coronavirus. In the absence of people, indoor air should be decontaminated using open UV irradiators and disinfecting aerosols.

In a non-COVID medical facility with exposures to COVID-19 patients, terminal disinfection should be performed by companies authorized to provide disinfection services or by trained staff. Bedding items should be disinfected in a sterilization chamber. Ventilation ducts are decontaminated using aerosol disinfectants or mist generating systems following the established protocols.

Measure for protecting medical personnel and patients include:

- irrigation therapy (nasal irrigation and gargling using hypertonic saline)

- topical medications that form a protective barrier;

- medication prophylaxis (recombinant IFNa, etc.) [6].

Establishing timely and accurate diagnosis of COVID-19 is critical for containing the spread of the virus in a healthcare facility.

According to the Sanitary Rules 3.1.3597-20 on the prophylaxis of the novel coronavirus infection (COVID-19), symptomatic healthcare workers at risk of occupational exposure to COVID-19 should be prioritized for laboratory testing. As a second-order priority, asymptomatic health care workers at risk for COVID-19 should be tested for the virus once a week until the first detection of lgG antibodies.

A few groups at risk for occupational exposure to COVID-19 can be identified among healthcare workers depending on the type of medical care they provide:

- very high occupational risk (must wear type I protective clothing): medical personnel of hospitals for infectious diseases exposed to patients with confirmed COVID-19; pathologists involved in performing autopsies of COVID-19 patients;

- high risk (must wear type II protective clothing): EMS teams involved in transportation of infected patients; medical personnel of COVID-19 hospitals following up patients suspected to have the infection; ER personnel; health workers delivering care to patients with respiratory infections, intensive care or specialized care (dentists, ophthalmologists, otorhinolaryngologists, pulmonologists); personnel of outpatient clinics, paramedical and midwifery stations who visit patients suspected to have COVID-19 in their homes; staff involved in performing routine and terminal disinfection;

- in addition, the high-risk group includes members of surgical teams performing urological, eye, thoracic, and septic emergency surgery in COVID-19 hospitals:

- medium occupational risk (must wear type III-IV protective clothing): all healthcare workers, including isolation facility staff and those who visit seemingly healthy individuals isolated in their homes (type III) [7].

The risk of COVID-19 spread in a healthcare facility increases during aerosol-generating diagnostic or therapeutic interventions, which include:

- endotracheal intubation;

- bronchoscopy;

- open suctioning of airways;

- nebulizer treatment;

- manual ventilation prior to intubation; putting the patient in the supine position; disconnecting the patient from the ventilator;

- non-invasive ventilation, including bilevel positive airway pressure ventilation and continuous positive pressure ventilation; high-frequency oscillatory ventilation;

- tracheostomy and cardiopulmonary resuscitation;

- upper Gl endoscopy;

- surgery involving use of high-speed cutters;

- emergency dental care (using high-speed burrs);

- sputum induction;

- high-flow $\mathrm{O}_{2}$ delivery, including nasal canula

Medical personnel performing aerosol-generating procedures must wear protection, as prescribed by the Sanitary Rules 3.1.3597-20 on the "Prophylaxis of the novel coronavirus infection (COVID-19):

- single-use respirators (filtration masks) filtering 99\% of solid and liquid particles or higher-level devices (respiratory helmet);

- eye protection (goggles or face shield);

- a biohazard gown (or another type or protective clothing), gloves, a water-proof apron.

Respirator donning and doffing, decontamination and disposal procedures must be strictly adhered to. An adequate seal of a respirator to the face cannot be achieved if the user has a beard or moustache [7].

At the beginning of the epidemic, healthcare workers contributed to the spread of COVID-19 due to inadequate protection, insufficient knowledge about the virus and PPE deficit. Due to high patient burden and atypical symptoms, many patients were misdiagnosed. Besides, on-site laboratory tests were unavailable.

The analysis of the accumulated data reveals that the primary cause of the nosocomial COVID-19 spread was poor compliance with infection prevention and control measures while delivering medical care to patients with suspected COVID-19, delayed diagnosis and nonadherence to disinfection standards.

Amendments introduced to Federal Law № 100 (April 1 , 2020) address responsibility for non-compliance with infection prevention and control measures (Article 236 of the Criminal Code). A healthcare worker found guilty of negligent transmission of infection to colleagues or patients will be fined 700,00 roubles or an equivalent of 18 monthly salaries. Noncompliant healthcare workers can lose their post or be banned 
from working in public health for 1-3 years or sentenced to 2 years in prison (Clause 1 of Article 236 of the Criminal Code).

The head of a medical facility can be held liable for noncompliance with infection prevention and control measures even if no individuals have been infected. The head of a medical institution is responsible for providing the medical personnel with respirators and disinfectants, organizing routine temperature checks and medical examination of the personnel prior to shift start aimed at identifying individuals with symptoms of respiratory infection.

Points to consider by heads of healthcare facilities are provided in the checklist below:

- Collect and compile normative documents on organizing medical care during the COVID-19 pandemic;

- Assign members of the medical personnel to specific tasks or issue a protocol explaining workflow during the pandemic;

- Implement prevention measures on the premises and among personnel (facemasks, hand hygiene with sanitizers, airing rooms, disinfection);

- Make sure you have sufficient supply of disinfectants, PPE, other medical products; check contracts, consignment bills, etc.

- Arrange personnel trainings on infection prevention and control (https://edu.rosminzdrav.ru/); familiarize them with normative documentation.

In order to be ready to respond to a COVID-19 threat, a healthcare facility must have an emergency plan specifying procedure for infection prevention and control in cases when a person (a patient or a staff member) is suspected to have an infectious disease. Annual training sessions are the most effective tool for testing the preparedness of a healthcare facility to an infection threat [8].

\section{CONCLUSION}

Measures for preventing and controlling the spread of COVID-19 in healthcare facilities are specified in the updated Interim Guidance on the Prophylaxis, diagnosis and treatment of the novel coronavirus infection (COVID-19) issued by the Russian Ministry of Healthcare; Order No. 198n dated March 19, 2020 on the Provisional workflow in a healthcare facility aimed at implementing preventive measures and reducing risks of spread of the novel coronavirus infection COVID-19 issued by the Russian Ministry of Healthcare; normative documents by Rospotrebnadzor (Sanitary Rules 3.1.3597-20 on the Prevention of the novel coronavirus infection (COVID-19), etc.

Algorithms for providing healthcare to a patient suspected to have COVID-19 have been developed, including safety precautions. For healthcare facilities, infection prevention and control includes strict adherence to sanitary precautions while delivering medical care to patients with suspected COVID-19 and timely detection of such patients. Routine temperature checks and medical examinations should be performed on healthcare workers, aiming to detect individuals with ARVI symptoms. Healthcare workers and support personnel must undergo regular trainings on infection prevention and control. Competence of healthcare workers, their ability to use PPE will determine the efficacy of measures for preventing the spread of COVID-19 in healthcare facilities.

\section{References}

1. Suranova T.G., Nikiforov V.V. Sostoyanie normativnoi pravovoi bazi po rlassifikacii biologicheskih ugroz [State of the regulatory framework for the classification of biological threats]/ Epidemiologiya i infekcionniye bolezni. 2016.T.21. № 4. pp. 188195. (In Russian).

2. Briko N.I., Kagramanyan L.N., Nikiforov V.V., Suranova T.G., Chernyavskaya O.P., Polezhaeva N.A. Pandemiya COVID-19. Meri borbi $\mathrm{s}$ ee rasprostraneniem $\vee$ Rossiyskoi Federacii [The COVID-19 pandemic. Measures to combat its spread in the Russian Federation] Epidemiologiya i vakcinoprofilaktika/ T.19. №2 - 2020. - pp. 4-12. (In Russian).

3. Drapkina O.M., Samorodskaya I.V., Sivtseva M.G., Kakorina E.P., Briko N.I., Cherkasov S.N., Zinserling V.A., Malkov P.G. Metodicheskiye aspekti otsenki zabolevaemosti, rasprostranennosti, letalnosti i smertnosti pri COVID-19. [COVID-19: urgent questions for estimating morbidity, prevalence, case fatality rate and mortality rate] Kardiovaskularnaya terapia i profilaktika 2020; 19(3):2585. doi:10.15829/1728-8800-20202585 (In Russian).

4. Thinbo Lyan «Spravochnik po profilaktike i lecheniyu COVID-19; [Handbook of COVID-19 Prevention and Treatment] / Clinical Hospital № 1, Zhejiang University School of Medicine. - Trans.

\section{Литература}

1. Суранова Т.Г., Никифоров В.В. Состояние нормативной правовой базы по классификации биологических угроз. / Эпидемиология и инфекционные болезни. 2016. Т. 21. № 4. C. 188-195.

2. Брико Н.И., Каграманян И.Н., Никифоров В.В., Суранова Т.Г., Чернявская О.П., Полежаева Н.A./ Пандемия COVID-19. Меры борьбы с ее распространением в Российской Федерации./ Эпидемиология и Вакцинопрофилактика. 2020.-Т. 19. № 2. С.

$$
\text { 4-12. }
$$

3. Драпкина О.М., Самородская И.В., Сивцева М.Г., Какорина Е.П., Брико Н.И., Черкасов С.Н., Цинзерлинг В.А., Мальков П.Г. Методические аспекты оценки заболеваемости, распространенности, летальности и смертности при COVID-19. Кардиоваскулярная терапия и профилактика. 2020;19(3):2585. doi:10.15829/1728-8800-2020-2585

4. Справочник по профилактике и лечению COVID-19 (Handbook 


\section{REVIEW}

of COVID-19 Prevention and Treatment) / под ред. Тинбо Лян. Первая клиническая больница, Медицинский факультет университета Чжэцзян. - Перевод на русский язык выполнен МИА «Россия сегодня». - 2020. - 69 с.

5. Брико Н.И., Брусина Е.Б., Зуева Л.П., Ефимов Г.Е., Ковалишена О.В., Стасенко В.Л., Фельдблюм И.В., Шкарин В.В. Эпидемиологическая безопасность - важнейшая составляющая обеспечения качества и безопасности медицинской помощи. / Вестник Росздравнадзора. 2014. № 3. С. 27-32.

6. Профилактика, диагностика и лечение новой коронавирусной инфекции COVID-19 Временные методические рекомендации / Москва, 2020. Том Версия 7 https://static-0. rosminzdrav.ru/system/attachments/attaches/000/050/584/ original/03062020_\%D0\%9CR_COVID-19_v7.pdf

7. Профилактика заноса и распространения COVID-19 в медицинских организациях. Временные методические рекомендации. Версия 2 от 14.05.2020. // Брико Н.И., Зуева Л.П., Любимова А.В., Светличная Ю.С., Брусина Е.Б., Ботвинкин А.Д., Петрухина М.И., Стасенко В.Л., Фельдблюм И.В., Квашнина Д.В., Чанышева Р.Ф., Ковалишена О.В., Суранова Т.Г. - 2020. -46 c. http://nasci.ru/?id=11907

8. Эпидемиология чрезвычайных ситуаций: Учебное пособие/ под ред.акад.РАН, проф. Брико Н.И., акад.РАН, проф. Онищенко Г.Г.- Москва: ООО «Издательство «Медицинское информационное агентство», 2020.-168 с. 